Культура и искусство 3(15) • 2013

В. О. Петров

\title{
Политекстовое взаимодействие
} в инструментальной композиции со словом

\begin{abstract}
Аннотация: в статье рассматривается одна из возможных разновидностей текстового присутствия в новом для второй половины XX в. жанре - инструментальной композиции со словом. Производится типология политекстового взаимодействия текстов в рамках инструментальной музыки: 1) принцип поочередного проведения (тексты следуют друг за другом в пространстве формы, например в разных частях произведения), 2) принцип арочности (один текст или текст одного автора проводится несколько раз, выполняя реминисцентную функцию), 3) принцип свободной компиляции (тексты разных авторов или созданные композитором используются хаотично, «разбросаны» в общей форме произведения; при этом, возможно проникновение текстов, сочиненных композитором в структуру цитируемого литературного источника). качестве примеров приводятся авангардные сочинения Ф. Караева, Б. Фернихоу, Ф. Ржевски.

Ключевые слова: искусствоведение, интертекстуальность, музыка, текст, слово, типология, методология, Ф. Ржевски, Б. Фернихоу, Ф. Караев.
\end{abstract}

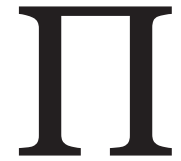

ричина весомости вербализации инструментального исполнительства в целом - использование богатых возможностей слуховой информации. Сочетание же речевой и неречевой информации дает возможность воспринимать идею "опредмеченной» и «огромные возможности инструментальной (то есть бессловесной) музыки», отмеченные Мазелем, перестают быть «загадочными», сближаясь по типу воздействия с жанрами не инструментальной музыки. В связи с этим необходимо указать, что произведения вызывают правильный ассоциативный образ, совпадающий с той образной «картиной», которую при сочинении «изображал» автор. Это происходит благодаря открытой программности, которой, по сравнению с «чистыми» инструментальными жанрами, обладают инструментальные композиции со словом. В данном случае авторы предлагают инструменталистам определенный текст, который необходимо петь или декламировать.

Существует несколько возможных классификаций используемых композиторами текстов. В первую очередь, тексты делятся на те, которые автор черпает в литературе (любые литературные источники - от писем, газетных заметок и научных текстов до высоких образцов литературной классики $\left.{ }^{1}\right)$ и те, которые сочиняет сам. Взаимозависимость текста

\footnotetext{
${ }^{1}$ Под литературной классикой понимается любое произведение литературы, являющееся образцовым (показательным) для той или иной эпохи, включая постмодернизм.
}

и музыки, характерная для вокальных форм, становится очевидной и в инструментальных композициях со словом. Выделим литературные источники, тексты, сочиненные композитором и тексты, которые необходимо придумывать во время исполнения опуса самим инструменталистам. Наибольший интерес представляет политекстовое взаимодействие текстов.

Действительно, в композиторской практике второй половины XX века встречаются такие инструментальные произведения, особенностью которых становится использование разных текстов - взятых из литературы, специально созданных самим автором, или предполагаемых для исполнительской импровизации. В данном случае можно говорить о политекстовом взаимодействии или интертекстуальности в рамках одного опуса ${ }^{2}$.

\footnotetext{
${ }^{2}$ Политекстовое взаимодействие ведет свою историю с XIII века, когда был сформирован жанр многоголосного мотета, в котором каждая мелодическая линия имела свой собственный текст. См. об этом: Румянцева $M$. Единство образа в политекстовом и полимелодическом выражении (на примере мотета XIII века) // Христианские образы в искусстве: Сб. трудов № 171. Вып. 2. / PАМ им. Гнесиных. / Сост. и отв. ред И. С. Стогний. М., 2008. С. 59-65. Т. Франтова по отношению к полифоническим произведениям использует термин «политекстовый контрапункт»: «целое сформировано как политекст - суммирование в одновременности нескольких частей, каждая из которых репрезентует традиционную форму самостоятельного текста». // Франтова T. В. Об одной современной художественной универсалии // FESTSCHRIFT Валентине Николаевне Холоповой: Материалы науч. конф. / Ред.-сост. О. В. Комарницкая. М.: Моск. гос. консерватория им. П. И. Чайковского, 2007. (Науч. тр. Моск. гос. консерватории, сб. 63). С. 22.
} 
Варианты синтеза текстов различны - это могут быть два (или более) литературных источника, текст литературного произведения может сочетаться с текстом композитора и т.д. Политекстовое взаимодействие применяется в больших по форме опусах, например, в циклах пьес, в которых одного текста было бы недостаточно для воплощения концепции. Можно представить следующую классификацию принципов взаимодействия текстов: 1) принцип поочередного проведения (тексты следуют друг за другом в пространстве формы, например - в разных частях произведения), 2) принцип арочности (один текст или текст одного автора проводится несколько раз, выполняя реминисцентную функцию), 3) принцип свободной компиляции (тексты разных авторов или созданные композитором используются хаотично, «разбросаны» в общей форме произведения; при этом, возможно проникновение текстов, сочиненных композитором в структуру цитируемого литературного источника).

Пример принципа поочередного проведения текстов - цикл «Положение вещей» (1991) для инструментального ансамбля Ф. Караева. В качестве источников им избираются текст австрийского поэта, представителя «конкретной поэзии» Э. Яндля и четыре фрагмента из романа швейцарского драматурга $M$. Фриша «Назову себя Гантенбайн». Тексты используются на языке оригинала, поэтому депоэтизации не происходит $^{3}$. Все приемы инструментального звукоизвлечения и голосового текстоизвлечения регламентированы. Идея Караева - приблизить инструментальную композицию

\footnotetext{
${ }^{3}$ Караев так охарактеризовал идею опуса: «Проекция Пяти пьес для оркестра ор.10 А. Веберна, эфемерно возникающая в лабиринтах оркестровой фактуры, составляет стержень этой композиции. В процессе исполнения оркестр неоднократно делится на несколько самостоятельных ансамблей - струнный и духовой квартеты, трио медных и струнных, дуэт контрабаса и бас-кларнета и др. Параллельно музыке А. Веберна, порой звучащей, а порой незримо присутствующей лишь в воображении дирижера, музыкальная ткань сочинения развивается по своим собственным законам. Возникающий в результате сложный комплекс взаимопроникающих структур на каждом новом витке развития достигает качественно иного уровня и приводит к смысловой кульминации, нередко не совпадающей с кульминацией динамической. Подобный горизонтальный сдвиг порождает некоторую зыбкость и неустойчивость формы, размываемой к тому же такими эпизодами, как декламация инструменталистами прозы Макса Фриша (во II части произведения. - В.П.), чтение стихов Эрнста Яндля (в IV части. - В.П.)». // Караев Ф.К. Лекция об инструментальном театре // Электронный ресурс (интернет-ссылка): http://www. karaev.net/t_lection_instrumtheater_r.html
}

к театру абсурда, где смешиваются игра и чтение текстов. Однако, произведение имеет трагедийное звучание и абсурдность его идеи проявляется лишь внутри литературных текстов. Два контрастных в своей основе текста - натуралистский стих Яндля, выявляющий причастность к игре слов, и трагически-саркастический текст Фриша - воспроизводятся поочередно. Приведем в пример текст Яндля «Отто мопс»: «мопс отто обормот / отто: вон мопс вон / мопс ommo mon mon / ommo: вот вот / отmо прёт кокс / отто прёт торт / отто: что ж мопс / отmо: мопс мопс / отто ждёт / мопс отmо хлоп хлоп / отто: вот он мопс / мопс oтmo cmon / мопса отто рвёт / отто: чёрточёрт» (перевод А. Глазовой). Его абсурдность понятна настолько, насколько понятно и стремление поэта к новациям в области произношения, сочетания гласносогласных звуков. При сопоставлении текстов Яндля с фрагментами романа Фриша в рамках произведения возникает эффект параномазии, доказанный А. Амраховой: «Как всегда, Э. Яндль, чьи стихи дают отличное сырье для всякого рода эффектов параномазии, и отрывок из романа М. Фриша “Назову себя Гантенбайн”, сама фабула которого, основанная на допущении двойственного развития событий, работает здесь на эстетику “возможных миров”. На уровне лексики - это обилие модальных операторов вероятно, или, наверняка, я представляю себе возможно... На уровне смысловой организации - постоянное моделирование интеллектуальной позиции как бъ» ${ }^{4}$.

Политекстовое взаимодействие заметно и в сюите «Дом под крышей» (1998) для ансамбля голландского композитора М. Паддинга, посвященной памяти А. Шенберга и состоящей из пяти частей: 1. «Спокойно», 2. «88 ударов в минуту», 3. «Текуче», 4. «Леверкюн говорит», 5. «Ритмически остро». В качестве литературных источников употребляется только проза на языке оригинала (немецком) - выражения A. Шенберга и фразы из романа Т. Манна «Доктор Фаустус». Герой произведения Манна - Леверкюн - «"несчастный гений”, носитель “извращенной гениальности”; истинно гениальный художник не нуждается в сделке

\footnotetext{
${ }^{4}$ Амрахова А. А. «Возможные миры...» // Музыкальная академия, 2004. № 1. С. 26.
} 
Культура и искусство 3(15) • 2013

с дьяволом» 5 - отождествляется с самим Шенбергом. В комментарии отмечено, что «В “Доме под крышей” ударник персонифицирует Шенберга. Он играет на маленьких инструментах, пытаясь извлечь много звуков, но не преуспевает в этом. Поэтому он говорит, поет и кричит, используя мегафон. Я использовал текст из неизвестной статьи Шенберга “Моя музыка, Новая музыка”, написанной им в 1930 году. Там он пытается объяснить, почему так важно писать композиторам новую музыку, остающуюся в безызвестности, все время. Он также подчеркивает важность знания истории музыки». Bce это (наличие пения и слов, большого исполнительского состава, лейтперсонажа, сквозной драматургии) говорят о проявлении в композиции Паддинга черт крупной вокально-инструментальной формы - one$p ы$, состоящей из пяти частей-актов.

В целом, музыка саркастична; Шенберг предстает как фигура, непонимающая, что еще можно придумать в области музыки, чтобы прослыть новатором. Ударник, олицетворяющий его, использует голос в I, III и IV частях. Причем, в I («Нужна ли новая музыка? Кому? Зачем? Она избыточна, как все новое. Что должно ее занимать? Чего ждет от нее слушатель? Чего ждет от нее эстетика? Почему пишет художник?...») и III («Но надо знать и все то, что ранее было сказано, или, по меньшей мере, то, что могло быть сказано и как могло быть сказано... Поэтому надо продолжать мысли») частях звучит текст Шенберга, а в IV - текст Манна ( Не смешно ли, что музыка долгое время считала себя средством спасения, тогда как она сама по себе, как и всякое искусство, жаждет спастись из "торжественной” изоляции, из одинокого бытия с образованной элитой...»), в связи с чем происходит их поочередное проведение. II часть - инструментальное интермеццо, а $\mathrm{V}$ часть - инструментальный финал, если апеллировать к рассмотрению цикла с точки зрения оперной драматургии. Паддингом не случайно вместо цитирования музыки Шенберга избирается цитирование его текстов, поскольку «литературное творчество композиторов во многом аналогично музыкальному, оно также является художественным

${ }^{5}$ Топер П. М. Трагическое в искусстве ХХ века // Художественные ориентиры зарубежной литературы XX века. / Редколлегия А. Б. Базилевский и др. М.: ИМЛИ РАН, 2002. C. 348. выражением или самовыражением, своеобразной автопрезентацией творца» ${ }^{6}$.

Примером проявления принципа текстовой арочности предстает цикл «Опус против природы» (1999) для фортепиано Б. Фернихоу. Здесь вновь образуется связь с оперой, поскольку, как указано в партитуре, цикл создан на «либретто» Ч. Бернштейна - американского поэта, причастного к «поэзии языка», предполагающей использование всевозможных приемов обращения с текстом, игру фонем и слогов, словесное «трюкачество». Одно из его поэтических сочинений - «Беспорядок» - стало литературной основой драматичной II части цикла, центра музыкальной вселенной композициит. В качестве вербальных «бонусов» в крайних частях композитор применяет собственные прозаические тексты, перекликающиеся с идеями «поэзии языка»: I часть - текст Фернихоу, II часть - текст Бернштейна, III часть - текст Фернихоу, в крайних частях - текст прозаический, в центре - поэтический. Все тексты используются на английском языке. Партитуре предпослана аннотация: «Тексты необходимо произносить приблизительно относительно звучания музыки. В некоторых моментах слова расположены так, чтобы их можно было произнести в точной координации с отдельными звуками фортепиано. Эта координация является намеренно спроецированной. В целом, тексты произносятся в конфронтации вербального и музыкального начал». Следовательно, Фернихоу использует декламацию двух типов:

тексты произносятся «приблизительно относительно звучания музыки», не указана его звуковысотность и ритмическая основа (во время пауз):

\footnotetext{
${ }^{6}$ Умнова И. Г. Литературные опыты в творчестве композиторов // Русское Слово в культурно-историческом и социальном контексте: Сборник статей по материалам Российской научно-практической конференции (Кемерово - Далянь, 22 октября 2010 г.): в 2 т. Кемерово: КемГУКИ, 2010. - T. I. C. 478.

${ }^{7}$ О специфике своих «синтетических» партитур и о смыслах использования текстов в этом и подобных этому сочинениях Фернихоу рассказал в интервью Е. Барбану: «Я действительно нередко использую литературу как своего рода зеркало... Необходимо сознавать, что музыка всегда погружена в поток культуры, включающей все формы человеческого восприятия. Мысль о том, что подлинно профессиональный музыкант должен иметь дело только с музыкой, ведет к отчуждению от нее. В наше время крайне важной необходимостью для композитора, его долгом стало приобщение к максимально возможному числу разновидностей современного творческого мышления». / Барбан Е. C. Контакты. Собрание интервью. СПб.: Композитор, 2006. С. 255.
} 
Знак, слово, речь, язык

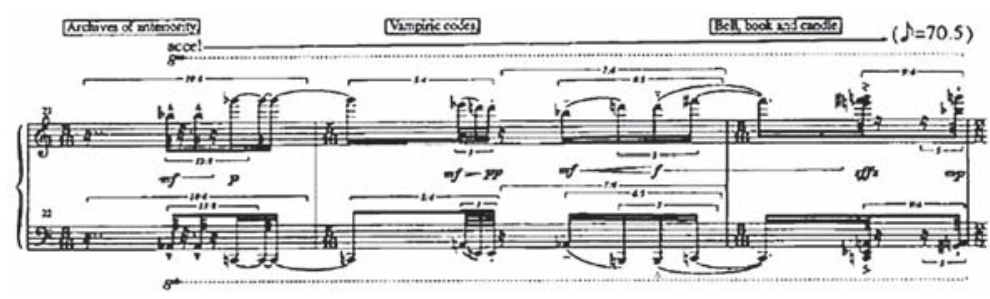

тексты произносятся в точной координации с отдельными звуками фортепиано, имеющими метроритмическое оформление:

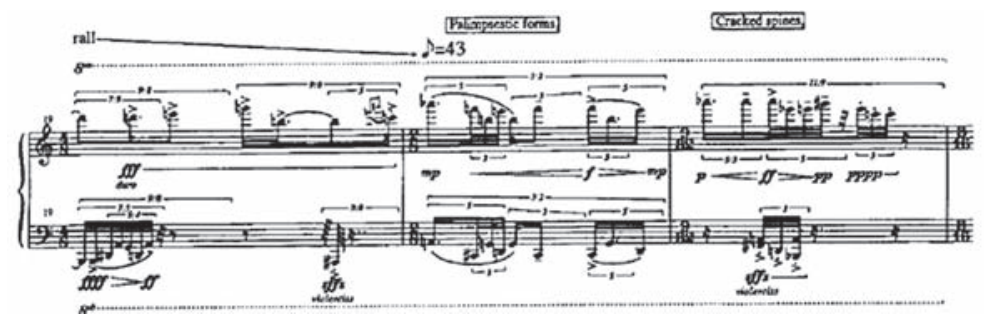

Смысловой константой I части служит индивидуализация всех уровней композиции. Фернихоу акцентирует эстетическую стратегию индивидуализации, свойственную алхимии эпохи Возрождения, что подчеркивается названием сочинения: «Опус против природы» - процесс против природы, способствующий преобразованиям в понимании бытия и трансформации человеческого сознания. Этой же точки зрения придерживался немецкий критик, философ и эссеист У. Бенджамин, сочетающий в своем учении идеи еврейского мессианства и марксистской теории. Ему и посвящена I часть произведения Фернихоу. Если говорить о музыкальном контексте, то процесс против природы музыкального искусства, имитируемый здесь, проявляется в наличии бессвязных и беспорядочных фрагментов. Объединяющим началом служит текст, изложенный в вопросно-ответной системе и восходящий смыслами к извечным вопросам философии бытия. Его начальные строки на русском языке имеют следующий смысл: «Тени рисуют силуэты на стенах самой жизни. Возражаете? / Бесспорно! / Изображения читают мысли? / Да, но это - семантический недостаток. / Временные рамки - вчера, сегодня, завтра - / развращенные данные!.. Так ли это?».

II часть, названная «Беспорядок» и являющаяся самой объемной в цикле, начинается инструментальным разделом, бурным, олицетворяющим название. В нем используются разные типы фактур, а применение секундовых соотношений в аккордах, разброс голосов в пространстве, преобладание синкоп дают возможность говорить о проявлении здесь джазовых элементов. Вербальный текст представляет череду несоотносимых между собой фраз, шире - «поэзию языка», к которой тяготел Бернштейн: «... from time to time in time to time... / ...into and out of... / ...like as as as as as like... / ...sealed off or shook up... / ...smack it... / ...or it'll zap you... / ...place your bets between the gaps... / ...is it real, or is it cropped...?»). Текст читается произвольно в метроритмическом отношении. Композитор указывает лишь на то, в каком месте должны быть прочитаны строфы. В контексте драматической музыки, насыщенной громкой динамикой, слова выкрикиваются, что дает возможность понять их смысловую сущность и распознать в условиях звукового хаоса.

III часть («Страх») не вносит изменений в образный мир цикла. Можно говорить о монообразности цикла: главенство одной идеи (размышление о времени) повлекло за собой слияние частей в образный микст, хотя каждая четко отграничена от другой. Созданные Фернихоу прозаические фразылозунги («Польза для истории - не есть польза для человека!», «Стремитесь к свободе! Это ваш остов!») в III части соединены с музыкальными звуками. Пианист каждый слог произносит вместе с определенным звуком, «в точной ритмической координации вербального и музыкального начал, с господством стаккатного произнесения». В 


\section{Культура и искусство 3(15) • 2013}

связи с этой спецификой вербальная часть партитуры пуантилистически "разбросана» в пространстве нотописи и графики.

Если говорить об идее «Опуса против природы» Фернихоу, то его, казалось бы, абсурдистская сущность, лежащая на поверхности благодаря тексту Бернштейна, превращается с точки зрения глобальных смыслов в идею философскую, выраженную прозаическими текстами, созданными композитором. В крайних частях - размышление о времени, о жизни и смерти как рамках бытия человека. Центральный по месту положения в цикле и значимый по смысловой определенности поэтический источник «Беспорядок» Бернштейна - избран неслучайно: Фернихоу констатирует абсурдность современного мира, в котором вопросы философии бытия (сформулированные в I части и находящие разрешение в лозунгах III части) тонут в общем пространстве мирового хаоса. На уровне концепции хаос подчеркивается не только наличием текстов, но и музыкальным контекстом - абсурдистским, как и взятое за основу «либретто».

Примером принципа свободной компиляции текстов предстает цикл «Дорога» (1992-2002) для фортепиано Ф. Ржевски - уникальный проект, содержащий в себе не только весь стилевой комплекс, присущий композитору, но и эпохи в целом ${ }^{8}$. В 90-х гг. Ржевски так характеризовал процесс работы над сочинением: «...я начал писать очень длинную композицию для фортепиано под названием “Дорога" ("Road"). Она будет coстоять из 64 частей (я называю их “милями”), объединенных в восемь более крупных разделов. Я хотел написать что-то вроде романа... Я очень ценю Даниэля Дефо, одного из первых романистов. Мне нравится, что в его книгах нет ни начала, ни конца. Идет повествование, в котором нет никакой структуры - точно так же, как в реальной жизни. Я тоже хотел написать пьесу, где события происходят беспричинно. Это сочинение тоже не имеет ни начала, ни конца, оно - часть чегото, что началось уже давно и будет еще долго продолжаться - просто отрывок жизни. Но не следует думать, что здесь есть какое-то литературное содержание. Речь о другом: мое сочинение по форме имеет нечто общее с литературой. В законченном виде, возмож-

\footnotetext{
${ }_{8}^{8}$ Маргарита Катунян - Виктор Екимовский. Поставангард глазами композиторов // Музыкальная академия, 1998. № 3-4. C. 123-124.
}

но, оно будет продолжаться 3 часа, но совершенно не обязательно слушать все целиком. Вы же не читаете за один день "Войну и мир": скажем, в первый день 50 страниц, во второй - 30 и так далее, каждый в своем собственном темпе». Части цикла Ржевски олицетворяют собой конкретные стадии жизни от ее начала с выбором нужного направления до ее финала. Финал жизненного пути трактуется композитором как Великий день. Судя по концепции произведения, жизнь главного его героя насыщена разными впечатлениями: если считать, что жизнь - есть дорога к смерти, становится понятным, почему в каждой из частей цикла присутствует трагическое мировосприятие.

Известные образцы литературы представлены фрагментами произведений $H$. Гоголя («Нос» в миле 32), М. Булгакова («Мастер и Маргарита» в миле № 44), А. Чехова («В овраге» в миле 48), Р.Л. Стивенсона («Юный полуночник» в миле 46), Л. Толстого («Крейцерова соната» в миле 58), К. Россетти (в миле 60). В ряде пьес применяются тексты композитора, отличающиеся высокой степенью философичности, отражающие авторский взгляд на идею сочинения. В миле 61 («Остановите войну!») текст - «Остановите войну! Или она остановит нас!»произносится в тишине в приблизительно заданном ритме. В миле 62 («Журчание») текст - «Где я? Что является мной? Что делает здесъ? Что это теперь?» - проговаривается в медленном темпе, в тихой динамике, без сопровождения. В миле 63 («Никуда») Ржевски использует несколько сочиненных фраз. Центральный персонаж пьесы - душа: здесь находятся ответы на вопросы, поставленные в «Журчании»: «Почему надо быть где-то? Я же здесь сейчас...». Среди других фраз: «В середине пути я остановлюсь и посмотрю, кто окружает меня», «Жизнь - серый туман и иногда - вспышки света», «И почему нет, почему нет? Ах...». В «Дороге» есть пьесы, в которых исполнителю необходимо сочинить вербальный текст самому. Ржевски всегда указывает где, необходимо вербально импровизировать (как, например, в миле 14 - «Следы»). Дословно слово «rattle» в переводе с английского языка означает «болтать без умолку»; композитор предлагает исполнителю говорить на протяжении пьесы, находясь в определенных регистровых границах. При этом, тексты композитора постоянно проникают в цитируемые литературные ис- 
точники: фразы Гоголя, Толстого, Булгакова прерываются «речью» Ржевски, которая выполняет комментирующую функцию.

Ряд текстов лег в основу композиции Ф. Ржевски «Падение империи» (2007) для ударника, играющего на разных инструментах (стручок, вибрафон, бас-барабан, колокол, глокеншпиль, фортепиано, саксофон). Концепция жизни и смерти, связанная с политическими взглядами композитора, потребовала включение в музыку текстов - писателей (Ч. Диккенс, М. Твен), сказочных персонажей (Матушка Гусыня), чьи цитаты, вышедшие из народа, известны в миpe, политиков ${ }^{9}$ (Т. Джефферсон, Д. Бьюкенен). Ржевски адаптирует их к современности, прибегая к собственным текстам. Это диктует наличие принципа свободной компиляции текстов. Однако, Ржевски образует логичную целостность текстового ряда, применяя один и тот же сочиненный текст в его начале и в конце. В связи с этим образуется текстовая арочность. Все тексты относятся к разным эпохам, но связаны тематически, используются на английском языке.

Во Вступлении потряхиванием стручка с семенами в заданном ритме создается необычный эффект: с одной стороны, отсутствие звуковысотности отрицает интонационное заполнение пространства, с другой стороны, - изображается шумовая картина хаоса, который станет основной образной сферой произведения. На этом фоне исполнитель в заданном ритме произносит слова третьего президента США Т. Джефферсона. Нехудожественный текст, взятый из одного из его манифестов, начинается так: «Всякий раз, когда я вспоминаю о том, что Господь справедлив, я дрожу за свою страну». Тема кары и правосудия, затронутая Джефферсоном, привлекла Ржевски именно в 2007 году в связи с непонятными ему политическими метаморфозами, происходящими в США и применением данной страной санкций против других государств. Соотношение шумового и вербального начал вызывает устрашающее впечатление, чему способствуют способы «исполнения» (помимо ритмической, четко представлена динамическая линия «игры») и продуманный план чтения текста, в котором акцентируются ключевые слова «...Господь справедлив...» (после произнесения слова «Господь» - сильный удар по стручку, чтобы шум заполнил простран-

\footnotetext{
9 О политических сюжетах в музыке Ржевски см.: Asplund Ch. Frederic Rzewski and spontaneous political music // Perspectives of New Music: academic theoretical journal, 1995. № 1. Pp. 418-441.
}

ство зала). Расстановка акцентов заставляет фиксировать эти слова.

В I акте - «Oхота на ангелов» - Ржевски предлагает собственный текст: «Oхота на ангелов является популярным времяпрепровождением в моей стране. Группа людей собирается на вершине и ждет появления ангелов. Вот они прибывают! Вы можете видеть их на горизонте, идущими через холмы: сотни, тысячи, даже, возможно, миллионы... Минуточку! Это не ангелы! Это - демоны, как те, которых вы видите на картинах Босха. Кто-то обманывал нас...». Текст читается в промежутках между игрой на вибрафоне, но непосредственно влияет на ее драматическое содержание. По-иному происходит сочетание вербального и музыкального начал во II акте - «Монстры». Здесь Ржевски использует прозаический текст Ч. Диккенса из новеллы «Колокола» (цикл «Рождественские повести»). У Диккенса, сознание категория внутреннего бытия, концентрация субъективных переживаний. В этой концентрации возможны всплески памяти, бушевание внутренне-природных страстей. Образы, ушедшие и возникающие в сознании, - есть монстры, не щадящие настоящего. Ирреальное содержание музыки исходит из образного «диктата» текста. Неслучайно композитор применяет бас-барабан и колокола. Чтение мрачного текста ${ }^{10}$ происходит контрапунктически относительно звучания ударных. Однако, сам текст не имеет метроритмической основы. В качестве вывода в конце части Ржевски добавляет сочиненную фразу: «Никто не может сказать...», обобщая слова Диккенса о хаотичности происходящих в сознании причин и следствий памяти.

В III акте («Три сына») используется текст МатушкиГусыни ${ }^{11}$,-трагическая считалочка,

\footnotetext{
${ }^{10}$ Герой новеллы Тоби Вэк любил слушать перезвон колоколов и представлять, что они с ним говорят. В одну предновогоднюю пору духи колоколов помогли Тоби узнать и понять человека, которого он любил: «Темны тяжелые тучи и мутны глубокие воды, когда море сознания, пробуждаясь после долгого штиля, отдает мертвых, бывших в нем. Чудища, вида странного и дикого, всплывают из глубин, воскресшие до времени, незавершенные; куски и обрывки несходных вещей перемешаны и спутаны; и когда, и как, и каким неисповедимым порядком одно отделяется от другого и всякое чувство, всякий предмет вновь обретает жизнь и привычный облик, - того не знает никто, хотя каждый из нас каждодневно являет собою вместилище этой великой тайны» (перевод Т. Озерской).

${ }^{11}$ Матушка Гусыня - персонаж британских сказок. В середине XVI века в Англии вышел сборник стихов Матушки гусыни, в котором были собраны образцы уличного фольклора.
} 


\section{Культура и искусство 3(15) • 2013}

повествующая о видах смерти ( $У$ старой женщины было три сына: / Джерри, Джеймс u Джон. / Джерри повесился, утонул Джеймс, / Джон погиб и не был найден... / И больше не было у старушки трех сыновей / Джерри, Джеймса и Джона...»). Музыкальный контекст усугубляет слова: исполнитель произносит их на фоне игры на трубочном барабане (сделан из разных звуковысотных трубок). Благодаря тому, что «все ноты должны резонировать» и звучать в пространстве, создается гулкая атмосфера: софия... Император не заботится о том, что вы думаете... Он заботится о нефти. И мысли, что вы - кто-то, зачеркните!»). Эти слова - непосредственный отклик композитора на события 2003 года - вторжение США в Ирак и организацию боевых действий. Человеческая жизнь, по мнению Ржевски, ничего не значит, если в ход идут корыстные мысли властителей. Отсюда жертвы, образам которых посвящены предыдущие и последующие части опуса. В «Основаниях» текст свободно декламиру-

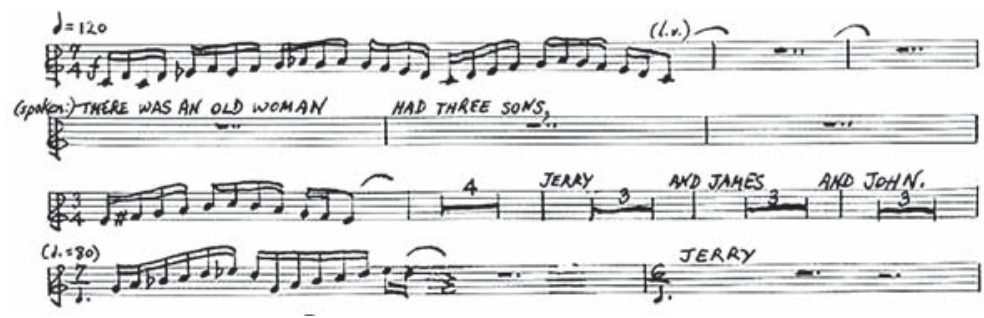

Акт IV - «Глобальное потепление» (текст Ржевски) - написан для четырех звуков, настроенных в терцию друг от друга: в музыкальном отношении применяется прием обыгрывания одного септаккорда. Во второй части декламируются слова: «Я не говорю плохо о глобальном потеплении. Я только забочусь о своем автомобиле... Я получаю только то, за что я заплатил. Я становлюсь плохим? Вы не можете ни на кого полагаться. Вы можете иногда доверять некоторым людям, но вы не знаете кто они u когда предадут...». Под конец акта текст читается обособленно - проявляется чередование вербальных и музыкальных фраз. При этом, происходит убыстрение темпа и динамизация исполнения к словам «...кто они и когда предадут...», являющимися кульминацией. После этого - заключительное обыгрывание звуков септаккорда.

В V акте - «Основание» (слова Ржевски) - текст произносится сразу же, без инструментального вступления ( ВВ начале не было ничего... В начале было что-то... Почему что-что и ничего?.. Мы думаем, что мы и есть то самое что-что... Мы - ничего. Мы никогда не знаем, что случиться, когда и где это все закончится... Но это - фило- ется вне музыкального сопровождения, что выделяет его.

Акт VI - «Жертва» для глокеншпиля имеет следующий нехудожественный текст, в основе которого лежит адаптированная к современности речь из пропагандистских высказываний Д. Бъюкенена («Все мы должны пожертвовать. Если каждая семья пожертвует одной жизнъю, одним ребенком, мы можем победить! Это время действий!»). Д. Бьюкенен - пятнадцатый президент США, действия которого привели к обострению отношений между Севером и Югом, к началу Гражданской войны. В начале XX века его имя сопоставлялось с именем действующего президента. Далее, в этом же акте Ржевски предоставляет свой резюмирующий текст: «США. 2007 год. Мир у наших ног! Мы побеждаем... Мы - перевернутая страница и мы знаем это. И настоящее - финальная точка! Только один предмет мы учим - историю. Но мы не учимся на ошибках истории». В нем композитор отрицает современные тенденции властвующей политики, во многом следующей не лучшим традициям одного из предшественников. Текст должен произноситься свободно, не совпадать ритмически с музыкой - перед нотой или только после нее:

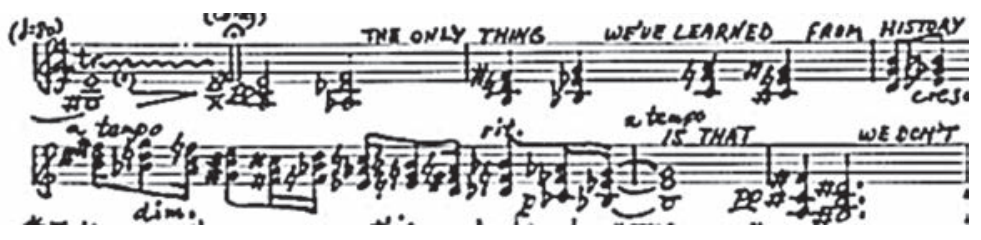


Акт VII назван композитором «Денъ отдыха» и написан на текст рассказа «Дневник Адама» из сборника «Письма с Земли» $M$. Твена («День отдыха... Как обычно никто ничего не делает. Никто, кроме нашего общества. В нем - множество злого роения и неоправданного пира. Выпивка, борьба, танец, азартная игра, смех, крики, напевы, мужчины, женщины, девочки, юноши... И шум! Выдувание рожков, рев медных инструментов, бум и грохот барабанов - все способно разорвать уши человека. Эти ужасные существа сегодня многочисленны... Посмотрите на себя!»). Ржевски добавляет в конце от себя: «Скажите это морским пехотинцам!». Композитор обвиняет американские войска в нарушении мирового спокойствия, идентифицируя их с «ужасными существами». В качестве инструментария в VII акте должны быть использованы бадья, шар, барабан или цилиндр любого материала, 30-50 см. в диаметре, содержащие шарики, бусинки или шары, которые вращаются внутри свободно, создавая звук, напоминающий о море или прибое. Однако, эти звуки служат воплощением не столько «моря или прибоя», сколько ассоциируются с шумом войны.

В созданном для сопрано-саксофона и фортепиано VIII акте («Охота на ангелов») используется текстовая реминисценция из I акта, что придает драматургии произведения целостность, а текстовому ряду - арочность. Но здесь присутствует иной способ его фиксации. Текст поделен на пять формант и выписан перед музыкальной частью партитуры: 1. "Охота на ангелов является популярным времяпрепровождением в моей стране», 2. «Группа людей собирается на вершине и ждет появления ангелов», 3. «Вот они прибывают! Вы можете видеть их на горизонте, идущими через холмы: сотни, тысячи, даже, возможно, миллионы...», 4. «Минуточку! Это не ангелы! Это - демоны, как те, которых вы видите на картинах Иеронима Босха», 5. «Кто-то обманывал нас...». Партитура представляет собой пять страниц инструментальной музыки, стремительной по темпу, изобилующей разного рода динамическими градациями. Аналогично I акту произнесение текста обособлено от музыки, хотя и влияет на общий характер ирреальной образности.

Монументальный опус «Падение империи» Ржевски предстает политически актуальным; в нем поднимаются вопросы бытия - общества, столкнувшегося с необходимостью воевать. Композитор ориентирует слушателя на исторический контекст, восстанавливая использованием текстов в едином хронотопе духовную близость ряда политических деятелей, персонажей и литературных героев. Ржевски комментирует высказывания политиков, добавляя собственные тексты, служащие дополнительным «скрепляющим» звеном формы, вставляет резюмирующие реплики внутрь цитирующихся источников, компилируя тексты.

Политекстовое взаимодействие - уникальное явление в области инструментальной композиции со словом, поскольку произведений, сочетающих в себе ряд текстов, как литературных, так и самостоятельно сочиненных автором, мало в количественном отношении. Они, как правило, объемны по форме (достаточно привести в пример цикл «Дорога» Ржевски, общее звучание которого достигает четырех часов); в них можно выявить признаки крупных вокально-инструментальных жанров (черты оперы в «Падении империи» Ржевски). В сочинениях используются разные принципы взаимодействия текстов: горизонтальное проведение текстов - в «Положении вещей» Караева, «Доме под крышей» Паддинга, текстовая арочность - в «Опусе против природы» Фернихоу, свободная компиляция текстов - в «Дороге» и «Падении империи» Ржевски, хотя в последнем случае компиляция сочетается с арочностью.

\section{Список литературы:}

1. Амрахова А. А. «Возможные миры...» // Музыкальная академия, 2004. № 1. С. 23-26.

2. Барбан Е. С. Контакты. Собрание интервью. - СПб.: Композитор, 2006.

3. Караев Ф. К. Лекция об инструментальном театре // Электронный ресурс (интернет-ссылка): http://www.karaev.net/t_lection_instrumtheater_r.html

4. Маргарита Катунян - Виктор Екимовский. Поставангард глазами композиторов // Музыкальная академия, 1998. № 3-4. С. 119-125.

5. Румянцева М. Единство образа в политекстовом и полимелодическом выражении (на примере мотета XIII века) // Христианские образы в искусстве: Сб. трудов № 171. Вып. 2. / РАМ им. Гнесиных. / Сост. и отв. ред И.С. Стогний. М., 2008. С. 59-65. 


\section{Культура и искусство 3(15) • 2013}

6. Топер П. М. Трагическое в искусстве XX века // Художественные ориентиры зарубежной литературы ХХ века. / Редколлегия А.Б. Базилевский и др. М.: ИМЛИ РАН, 2002. С. 331-377.

7. Умнова И. Г. Литературные опыты в творчестве композиторов // Русское Слово в культурно-историческом и социальном контексте: Сборник статей по материалам Российской научно-практической конференции (Кемерово - Далянь, 22 октября 2010 г.): в 2 т. Кемерово: КемГУКИ, 2010. - Т. I. C. 470-479.

8. Франтова Т. В. Об одной современной художественной универсалии // FESTSCHRIFT Валентине Николаевне Холоповой: Материалы науч. конф. / Ред.-сост. О.В. Комарницкая. М.: Моск. гос. консерватория им. П.И. Чайковского, 2007. (Науч. тр. Моск. гос. консерватории, сб. 63). С. 17-24.

9. Asplund Ch. Frederic Rzewski and spontaneous political music // Perspectives of New Music: academic theoretical journal, 1995. № 1. Pp. 418-441.

\section{References (transliteration):}

1. Amrakhova A. A. «Vozmozhnye miry...» // Muzykal'naya akademiya, 2004. № 1. S. 23-26.

2. Barban E. S. Kontakty. Sobranie interv'yu. — SPb.: Kompozitor, 2006.

3. Karaev F. K. Lektsiya ob instrumental'nom teatre // Elektronnyy resurs (internet-ssylka): http://www.karaev.net/t_lection_instrumtheater_r.html

4. Margarita Katunyan - Viktor Ekimovskiy. Postavangard glazami kompozitorov // Muzykal'naya akademiya, 1998. № 3-4. S. 119-125.

5. Rumyantseva M. Edinstvo obraza v politekstovom i polimelodicheskom vyrazhenii (na primere moteta KhIII veka) // Khristianskie obrazyviskusstve: Sb. trudov № 171. Vyp. 2. / RAM im. Gnesinykh. / Sost. i otv. red I.S. Stogniy. M., 2008. S. 59-65.

6. Toper P. M. Tragicheskoe v iskusstve KhKh veka // Khudozhestvennye orientiry zarubezhnoy literatury KhKh veka. / Redkollegiya A.B. Bazilevskiy i dr. M.: IMLI RAN, 2002. S. 331-377.

7. Umnova I. G. Literaturnye opyty v tvorchestve kompozitorov // Russkoe Slovo v kul'turno-istoricheskom i sotsial'nom kontekste: Sbornik statey po materialam Rossiyskoy nauchno-prakticheskoy konferentsii (Kemerovo - Dalyan', 22 oktyabrya 2010 g.): v 2 t. Kemerovo: KemGUKI, 2010. - T. I. S. 470-479.

8. Frantova T. V. Ob odnoy sovremennoy khudozhestvennoy universalii // FESTSCHRIFT Valentine Nikolaevne Kholopovoy: Materialy nauch. konf. / Red.-sost. O.V. Komarnitskaya. M.: Mosk. gos. konservatoriya im. P.I. Chaykovskogo, 2007. (Nauch. tr. Mosk. gos. konservatorii, sb. 63). S. 17-24.

9. Asplund Ch. Frederic Rzewski and spontaneous political music // Perspectives of New Music: academic theoretical journal, 1995. № 1. Rr. 418-441. 